\title{
Humoral Autoimmunity in Type 1 Diabetes: Prediction, Significance, and Detection of Distinct Disease Subtypes
}

\author{
Massimo Pietropaolo ${ }^{1}$, Roberto Towns ${ }^{1}$, and George S. Eisenbarth ${ }^{2}$ \\ ${ }^{1}$ Laboratory of Immunogenetics, The Brehm Center for Diabetes Research, Department of Internal \\ Medicine, University of Michigan Medical School, Ann Arbor, Michigan 48105 \\ ${ }^{2}$ Barbara Davis Center for Childhood Diabetes, University of Colorado Denver, Aurora, Colorado 80045 \\ Correspondence: George.Eisenbarth@ucdenver.edu
}

Type 1 diabetes mellitus (T1D) is an autoimmune disease encompassing the T-cell-mediated destruction of pancreatic $\beta$ cells and the production of autoantibodies against islet proteins. In humoral autoimmunity in T1D, the detection of islet autoantibodies and the examination of their associations with genetic factors and cellular autoimmunity constitute major areas in both basic research and clinical practice. Although insulin is a key autoantigen and may be primus inter pares in importance among T1D autoantigens, an abundant body of research has also revealed other autoantigens associated with the disease process. Solid evidence indicates that autoantibodies against islet targets serve as key markers to enroll newly diagnosed T1D patients and their family members in intervention trials aimed at preventing or halting the disease process. The next challenge is perfecting mechanistic bioassays to be used as end points for disease amelioration following immunomodulatory therapies aimed at blocking immune-mediated $\beta$-cell injury and, in turn, preserving $\beta$-cell function in type 1 diabetes mellitus.

\begin{abstract}
$\Delta$ famous influential scientist of the past milAlennium, the Renaissance polymath Leonardo da Vinci (1452-1519), wrote: "The supreme misfortune is when theory outstrips performance." This is a situation that perhaps shares some similarities with our knowledge on the pathoetiology of autoimmune diabetes. The discovery of islet autoantigens and the identification of their immunodominant epitopes has shifted emphasis from epidemiological to mechanistic and exploratory intervention studies using these antigens, such as insulin, to prevent
\end{abstract}

T1D. An incredibly large number of immunomodulatory strategies were and are currently applied to prevent diabetes in animal models of the disease, such as the NOD mouse (Shoda et al. 2005). Many therapeutic strategies may delay or prevent diabetes in NOD mice, and the most promising ones are currently being tested in humans (Skyler 2011).

Type 1 diabetes mellitus was not always considered the classical autoimmune disease it is now known to be. For instance, insulin-dependent diabetes was known to occur occasionally

Editors: Jeffrey A. Bluestone, Mark A. Atkinson, and Peter Arvan

Additional Perspectives on Type I Diabetes available at www.perspectivesinmedicine.org

Copyright (C) 2012 Cold Spring Harbor Laboratory Press; all rights reserved; doi: 10.1101/cshperspect.a012831

Cite this article as Cold Spring Harb Perspect Med 2012;2:a012831 
M. Pietropaolo et al.

in the Autoimmune Polyendocrine Syndrome I (APS I), a classic autoimmune syndrome with T cell and B-cell antibody abnormalities directed at adrenal, parathyroid, gonadal, thyroid, and other tissues. However, diabetes mellitus was not a constant, necessary, or sufficient feature of APS I. This condition is now known to be caused by mutations in the autoimmune regulator gene (AIRE) (Husebye and Anderson 2010). In 1974, Bottazzo et al. (1974) reported that sections of human pancreas treated with sera of diabetic patients who also had Addison's disease and myxedema showed cytoplasmic fluorescence over islets of Langerhans. This response was termed cytoplasmic islet cell antibodies (ICA). Furthermore, the existence of insulin autoantibodies and other autoantibodies against various islet proteins was not uncovered until years later. It was in 1983 that insulin autoantibodies were reported in sera of newly diagnosed patients with T1D, before any treatment with exogenous insulin (Palmer et al. 1983). In this finding, improvements of the sensitivity of the insulin antibody assay were instrumental for the determination that about onehalf of newly diagnosed patients had autoantibodies that bound ${ }^{125}$ I-labeled insulin.

Following the early discoveries on humoral autoimmunity in T1D, there has been a remarkable expansion in the detection of T1D-associated autoantibodies (Table 1) as well as in the characterization of the molecular basis of the antigenicity of their target proteins (Atkinson and Eisenbarth 2001; Pietropaolo and Eisenbarth 2001). This expansion has led to the uncovering of specific antigenic determinants, the development of biochemically defined immunoassays, and also to coordinated efforts to standardize assays across laboratories (Bonifacio et al. 2010b). However, it should be emphasized that T1D is primarily a T-cell-mediated disease. In humans, this conclusion was supported by a report of X-linked agammaglobulinemia in whom typical T1D developed at the age of 14 yr (Martin et al. 2001). This report shows that T1D can occur in the complete absence of B cells and autoantibodies. This observation led to the conclusion that B cells are not an essential requirement for the development of this disease and that the principal effector mechanisms are mediated by T cells. Thus, although the presence of islet autoantibodies may not be a sine qua non feature of autoimmune diabetes, advances in detection of humoral autoimmunity have had critical implications in the identification of at-risk subjects that can become participants in clinical trials to assess immunomodulatory strategies to prevent and treat T1D.

\section{ASSAY STANDARDIZATION AND HARMONIZATION}

Currently, the consensus on methodological standardization encompasses assays to detect autoantibodies against four major islet autoantigens, namely, insulin, glutamic acid decarboxylase (GAD), the neuroendocrine antigen ICA512/IA-2, I-A2 $\beta$ (phogrin), and the zinc transporter ZnT8. Although there is an overall agreement regarding the methodologies to assess humoral autoimmunity in T1D, the ability to detect T1D-related autoantibodies and to accurately measure their titer has also clear organizational implications because of the need to interpret values across laboratories, populations, and countries and to promote the development of assay systems that can improve the comparative assessment of results.

These strategies have included the adoption of a serum reference standard for GAD and IA-2 antibodies by the World Health Organization (WHO) and the creation of the Diabetes Antibody Standardization Program (DASP), which was established in 2000 by the Immunology of Diabetes Society (IDS) and the Centers for Disease Control and Prevention (CDC) (Verge et al. 1998; Bonifacio et al. 2002). It has been DASP activities that have led to the recognition of insulin, GAD, IA-2, and ZnT8 as the main targets for the validation and standardization of assays. The need to provide a broader basis for comparison of results has also evolved into harmonization efforts to produce unified protocols that can take into account differences in standards such as the WHO standard, relative to the use of common standards used by the National Institute of diabetes and Digestive and Kidney 
Humoral Autoimmunity in Type 1 Diabetes

Table 1. Most characterized islet autoantigens associated with type 1 diabetes

\begin{tabular}{|c|c|c|c|}
\hline & Localization & Humoral response & Cellular response \\
\hline Insulin $^{a}$ & $\begin{array}{l}\text { Secretory granules } \\
\text { pancreatic } \beta \text { cells } \\
\text { Human thymus and PAE } \\
\text { cells ( peripheral antigen } \\
\text { expressing cells) }\end{array}$ & $\begin{array}{l}\text { Insulin autoantibodies are found } \\
\text { in virtually } 100 \% \text { of young } \\
\text { children ( }<5 \text { yr of age) before } \\
\text { the onset of Type } 1 \text { diabetes } \\
\text { Correlation with younger age and } \\
\text { fast rate of progression to } \\
\text { insulin requirement in first- } \\
\text { degree relatives of IDDM } \\
\text { patients } \\
\text { Prophylactic subcutaneous } \\
\text { injection of insulin, oral and } \\
\text { intranasal administration } \\
\text { prevents type } 1 \text { diabetes in } \\
\text { NOD mice }\end{array}$ & $\begin{array}{l}\text { PBLs from humans and } \\
\text { NOD mice react with } \\
\text { insulin } \beta \text {-chain }\end{array}$ \\
\hline $\begin{array}{l}\text { GAD } 65^{\mathrm{a}} \text { and } \\
\text { GAD67 }\end{array}$ & $\begin{array}{l}\text { Synaptic-like microvesicles } \\
\text { of neuroendocrine cells } \\
\text { Present in testis and ovary } \\
\text { Human thymus and PAE } \\
\text { cells }\end{array}$ & $\begin{array}{l}\text { A subset of } 64-\mathrm{kDa} \\
\text { autoantibodies recognize GAD } \\
\text { Autoantibodies to GAD65 are } \\
\text { present in } 70 \%-80 \% \text { of pre- } \\
\text { diabetic subjects or newly } \\
\text { diagnosed diabetic patients } \\
\text { GAD antibodies are also detected } \\
\text { in patients with stiff man } \\
\text { syndrome, and with } \\
\text { autoimmune thyroid disease } \\
\text { Radioimmunoassay of in vitro } \\
\text { transcribed/translated GAD65 } \\
\text { is useful for large-scale } \\
\text { screening }\end{array}$ & $\begin{array}{l}\text { PBL responses to } \\
\text { GAD65 in newly } \\
\text { diagnosed diabetic } \\
\text { patients and in NOD } \\
\text { mice }\end{array}$ \\
\hline $\begin{array}{l}\text { ICA512(IA-2) }{ }^{\mathrm{a}} \text { and } \\
\text { phogrin (IA-2 } \beta \text { ) }\end{array}$ & $\begin{array}{l}\text { Neurosecretory granules } \\
\text { ( pancreatic } \beta \text { cells, } \\
\text { CNS, pituitary, adrenal) } \\
\text { Human thymus and PAE } \\
\text { cells }\end{array}$ & $\begin{array}{l}\text { Autoantibodies to ICA512 (IA-2) } \\
\text { are present in } \sim 60 \% \text { of pre- } \\
\text { diabetics or newly diagnosed } \\
\text { IDDM patients } \\
\text { Relationship between } 37,000 \text { - and } \\
40,000 \text {-Da tryptic fragments } \\
\text { and ICA512(IA-2) } \\
\text { Radioimmunoassay of in vitro } \\
\text { transcribed/translated } \\
\text { ICA512(IA-2) is useful for } \\
\text { large-scale screening }\end{array}$ & $\begin{array}{l}\text { PBL responses in newly } \\
\text { diagnosed diabetic } \\
\text { patients }\end{array}$ \\
\hline ZnT8 $\left(\right.$ Slc30A8) ${ }^{\mathrm{a}}$ & $\begin{array}{l}\text { Zn transporter, a member } \\
\text { of the cation diffusion } \\
\text { facilitator family } \\
\text { showing abundant } \\
\text { expression in } \beta \text { cells } \\
\text { Expressed also extra- } \\
\text { pancreatically }\end{array}$ & $\begin{array}{l}\text { Targeted by autoantibodies in } \\
60 \%-80 \% \text { of newly diagnosed } \\
\text { T1D patients and in } \sim 26 \% \text { of } \\
\text { patients negative for other islet } \\
\text { autoantibodies } \\
\text { Relevant polymorphic variants } \\
\text { are Trp-325 and Arg-325 }\end{array}$ & $\begin{array}{l}\text { Autoreactive T cells to } \\
\text { ZnT8 found in } \\
\text { human T1D }\end{array}$ \\
\hline
\end{tabular}


M. Pietropaolo et al.

Table 1. Continued

\begin{tabular}{|c|c|c|c|}
\hline & Localization & Humoral response & Cellular response \\
\hline $\begin{array}{l}\text { Islet cell autoantigen } \\
69 \mathrm{kDa} \text { (ICA69) }\end{array}$ & $\begin{array}{l}\text { Predominantly } \\
\text { neuroendocrine tissues } \\
\text { Human and mouse } \\
\text { thymus }\end{array}$ & $\begin{array}{l}\text { Autoantibodies to ICA69 can } \\
\text { be detected in } 43 \% \text { of pre- } \\
\text { diabetic subjects by } \\
\text { Western blotting }\end{array}$ & $\begin{array}{l}\text { Association between } \\
\text { HLA-DR3 and PBL } \\
\text { responses in newly } \\
\text { diagnosed type } 1 \\
\text { diabetics }\end{array}$ \\
\hline Chromogranin A & $\begin{array}{l}\text { Neurosecretory granules } \\
\text { Neuroendocrine tissues }\end{array}$ & $\begin{array}{l}\text { Circulating ChgA found in NOD } \\
\text { mice }\end{array}$ & $\begin{array}{l}\text { Autoreactive T cells to } \\
\text { ChgA found in NOD } \\
\text { mice }\end{array}$ \\
\hline Carboxypeptidase $\mathrm{H}$ & Neurosecretory granules & $\begin{array}{l}\text { Autoantibodies to } \\
\text { carboxypeptidase } \mathrm{H} \text { found } \\
\text { in } \sim 20 \% \text { of pre-diabetics }\end{array}$ & Present \\
\hline Ganglioside GM2-1 & Pancreatic islet cells & $\begin{array}{l}\text { Autoantibodies to GM2-1 } \\
\text { detected in } \sim 80 \% \text { of pre- } \\
\text { diabetic subjects and NOD } \\
\text { mice }\end{array}$ & $?$ \\
\hline Imogen 38 (38 kDa) & $\begin{array}{l}\text { Mitochondria widely } \\
\text { distributed with variable } \\
\text { levels of expression }\end{array}$ & $\begin{array}{l}\text { Presence of circulating antibodies } \\
\text { to } 38-\mathrm{kDa} \text { proteins } \\
\text { Possible presence of antibodies to } \\
\text { imogen } 38\end{array}$ & $\begin{array}{l}\text { PBLs from newly } \\
\text { diagnosed diabetics } \\
\text { proliferate to imogen } \\
38\end{array}$ \\
\hline Glima 38 & $\begin{array}{l}\text { Amphiphilic N-Asp } \\
\text { glycated } \beta \text {-cell } \\
\text { membrane protein that } \\
\text { is expressed in islets and } \\
\text { neuronal cell lines }\end{array}$ & $\begin{array}{l}\text { Autoantibodies to Glima } 38 \\
\text { can be detected in } 14 \%-22.7 \% \\
\text { of newly diagnosed diabetics } \\
\text { and pre-diabetics. The majority } \\
\text { of these patients are negative } \\
\text { for GAD65 and/or ICA512(IA- } \\
\text { 2) autoantibodies }\end{array}$ & $?$ \\
\hline Peripherin & Neuronal cells & $\begin{array}{l}\text { Autoantibody response against } \\
\text { peripherin in NOD mice and in } \\
\text { patients with type } 1 \text { diabetes } \\
\text { and other autoimmune } \\
\text { disorders }\end{array}$ & $\begin{array}{l}\text { T-cell responses against } \\
\text { peripherin in NOD } \\
\text { mice }\end{array}$ \\
\hline $\begin{array}{l}\text { Heat-shock protein } \\
\quad(\text { Hsp60) }\end{array}$ & Ubiquitously inducible & $\begin{array}{l}\text { Antibodies to Hsp60 in pre- } \\
\text { diabetic NOD mice }\end{array}$ & $\begin{array}{l}\text { Hsp60-reactive T cells } \\
\text { can accelerate disease } \\
\text { in pre-diabetic NOD } \\
\text { mice }\end{array}$ \\
\hline
\end{tabular}

${ }^{\mathrm{a}}$ Biochemical autoantibody assays readily available for large screening programs.

diseases (NIDDK) consortia laboratories (Bonifacio et al. 2010b).

A study by Bonifacio et al. (2010a) on the harmonization of GAD and IA-2 autoantibody assays by NIDDK consortia laboratories, using large-volume calibrators and common protocols, indicated that common protocols and use of large-volume working calibrators are effective measures to ensure consistency in autoantibody measurements, although the results were com- parable but not identical. However, other studies indicate that complete harmonization and cross-validation and interpretation of results will require additional effort.

Even though there has been considerable progress in standardizing GAD65 and IA-2 autoantibody assays, the insulin autoantibody assay is least standardized, with most laboratories in DASP workshops having less than acceptable sensitivity and/or specificity. This probably 
relates to the very low capacity of T1D autoantibodies and a limited conformational epitope recognized by these antibodies that is obscured if insulin is bound to solid phase. We have recently developed an electrochemiluminescent insulin autoantibody assay using pro-insulin as target antigen that appears to enhance sensitivity and specificity (Yu et al. 2012).

The advent of biochemically defined assays has permitted the development of chimeric and hybrid antigen constructs that can simultaneously assess the presence of autoantibodies against more than one antigen. This strategy is illustrated in a recent study with a triple chimeric islet autoantigen containing key antigenic determinants to IA-2 and key variants of the $\mathrm{Zn}$ transporter (ZnT8WR) as an accurate and relevant T1D antigen (Yu et al. 2010). The use of these chimeric assays holds promise to save labor and resources to more efficiently screen atrisk populations.

\section{DISCOVERY OF AUTOANTIGENS AND RELEVANT EPITOPES BASED ON AUTOANTIBODIES, MAJOR T1D- ASSOCIATED ISLET AUTOANTIBODIES CURRENTLY ASSAYED}

Initial studies by Atkinson et al. (1993) identified a subset of islet cell antibodies (ICA) associated with a more clinically significant pancreatic $\beta$-cell injury in a subgroup of first-degree relatives of T1D probands. This subset of ICA was termed "non-GAD reactive" because ICA reactivity could only be partially blocked by GAD65 (Atkinson et al. 1993). This observation implied that multiple islet autoantigens are recognized by T1D-specific humoral responses. We subsequently found that a subset of cytoplasmic ICA is associated to a more rapid progression to insulin-requiring diabetes in GAD65 and IA2 antibody-positive relatives as compared with relatives with GAD65 and IA2 antibodies without ICA. This ICA reactivity more than likely is caused by a subset of ICA-recognizing unidentified islet autoantigen(s) (Pietropaolo et al. 2005).

As autoimmunity in T1D progresses from initial activation to a chronic state, there is often a higher number of islet autoantigens reacting with $\mathrm{T}$ cells and autoantibodies. This condition is termed "epitope spreading." Compelling evidence indicates that islet autoantibody responses against multiple islet autoantigens are associated with progression to overt disease (Verge et al. 1996). Several additional T1D-related autoantigens have been identified, which include islet cell autoantigen $69 \mathrm{kDa}$ (ICA69), the islet-specific glucose-6-phosphatase catalytic subunit-related protein (IGRP), chromogranin A (ChgA), the insulin receptor, heat shock proteins, and the antigens jun-B, 16, CD38 (Pietropaolo and Eisenbarth 2001), peripherin, and glial fibrillary acidic protein (GFAP), and the like (Table 1) (Winer et al. 2003).

The existence of IgG immunoglobulins directed to epitopes of islet antigens strongly implies the influence of T-cell participation in the autoimmune response. Naturally processed epitopes of islet autoantigens represent the targets of effector and regulatory $\mathrm{T}$ cells in controlling $\beta$-cell-specific autoimmune responses (Di Lorenzo et al. 2007). In particular, naturally processed HLA class II allele-specific epitopes recognized by $\mathrm{CD} 4^{+} \mathrm{T}$ cells (corresponding to the intracellular domain of IA2) were identified after native IA2 antigen was delivered to EBVtransformed B cells and peptides were eluted and analyzed by mass spectrometry (Peakman et al. 1999). Additionally, evidence suggests a synergistic pro-inflammatory role for plasmacytoid dendritic cells and IA-2 autoantibodies in T1D (Allen et al. 2009). These studies may lead to the identification of novel naturally processed epitopes recognized by $\mathrm{CD} 4^{+} \mathrm{T}$ cells, which, in turn, may represent potential therapeutic agents for T1D, either in native form or as antagonistic altered peptide ligands.

\section{Insulin Autoantibodies}

Insulin is a hormone produced by the pancreatic $\beta$ cells, which is not only central to regulating carbohydrate and fat metabolism, but is also central in its pathological role as a T1D autoantigen. Insulin is the predominant secretory product of pancreatic $\beta$ cells whose autoimmune destruction leads to insulin deficiency 
M. Pietropaolo et al.

and consequent metabolic decompensation of glucose homeostasis (Nakayama et al. 2005). Investigations of the immunologically relevant regions of the insulin molecule conducted in NOD mice revealed that the 9-23 amino acid sequence of the insulin B chain (termed B9-23) and the effect of intracellular processing of molecules, such as insulin, within the $\beta$ cell can lead to formation of immunogenic epitopes (Fig. 1) (Crawford et al. 2011).

A high titer of insulin autoantibodies (IAA) at younger ages is consistent with the concept that these patients develop a more aggressive dis- ease course. In particular, insulin autoantibodies levels > $2000 \mathrm{nU} / \mathrm{mL}$ are almost exclusively found in patients who progress to T1D before age $5 \mathrm{yr}$, and less than half of individuals developing T1D after age 15 yr carry detectable levels of IAA.

A study from the Finnish Type 1 Diabetes Prediction and Prevention Study, comprising a large population of 2448 genetically at-risk children (Kimpimaki et al. 2001), showed that IAAs are usually the first islet autoantibody to appear in the natural history of T1D and a powerful identifier of disease progression in children followed from birth (Steck et al. 2011).

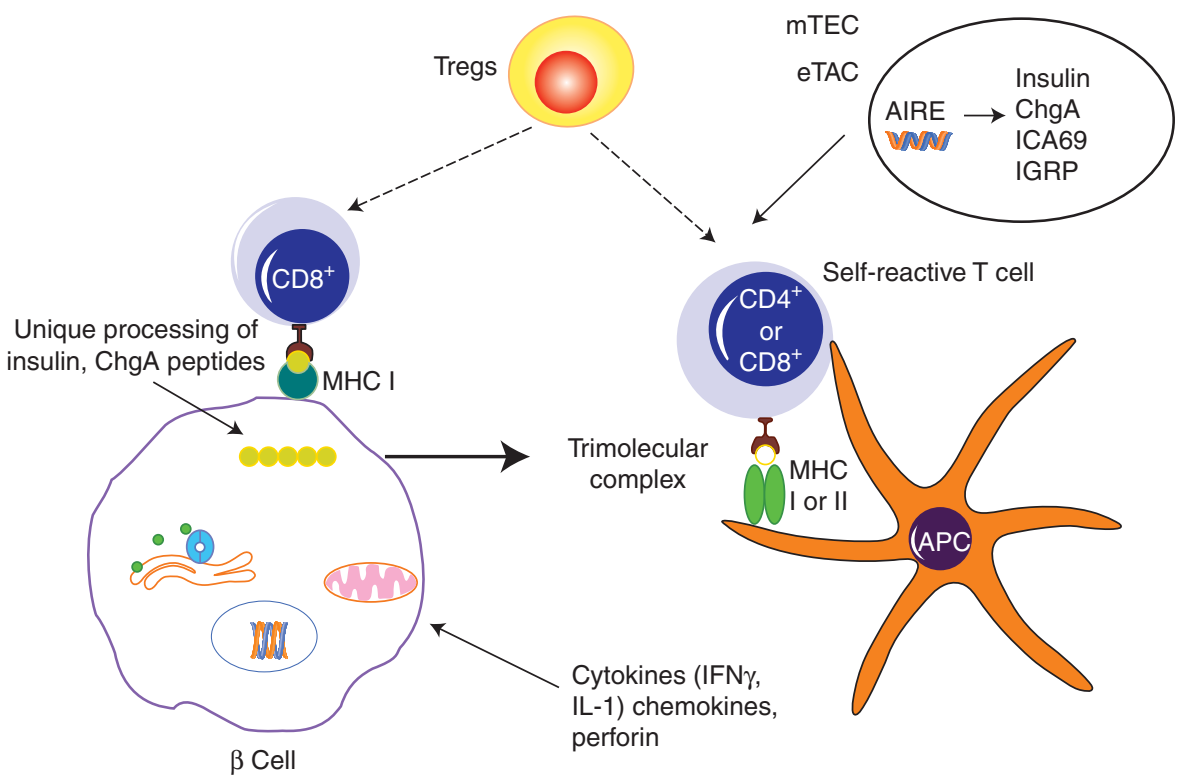

Figure 1. Unique processing of $\beta$-cell proteins may lead to antigenicity. The $\beta$ cell itself not only produces target antigens, but also it modifies molecules, such as insulin and ChgA, by cleavage at critical sites creating peptides recognized by pathogenic T-lymphocytes (Stadinski et al. 2010; Crawford et al. 2011). Processing of molecules such as insulin within the $\beta$ cell generates peptides that are then taken up by antigen-presenting cells either as whole dead $\beta$ cells or specifically granules of $\beta$ cells for eventual further processing/presentation of islet peptides to self-reactive T cells (Crawford et al. 2011). The trimolecular complex, involving an (MHC-presenting molecule)/( peptide in appropriate "register")/(T-cell receptor recognizing both), like a lock and key is an essential recognition unit for adaptive organ-specific autoimmunity. The fact that in the thymus the absence of this type of processing combined with the low affinity of B:9-23 binding to $\mathrm{IA}^{\mathrm{g} 7}$ in register 3 may explain the escape of insulin-specific $\mathrm{CD} 4^{+} \mathrm{T}$ cells from the mechanisms that usually eliminate self-reactive $\mathrm{T}$ cells. Both regulatory (Treg) and effector T-lymphocytes are produced, and their balance is crucial for maintaining tolerance (Bluestone and Boehmer 2006). Evidence suggests that the inappropriate MHC class I expression detected in pancreatic islets in T1D may not be solely due to the effect of cytokines such as IFNy (Bottazzo et al. 1985). It is conceivable that this molecule may function as an indicator of cell stress, likely present in residual pancreatic islets from T1D patients, and may be recognized by a subset of T cells in an unusual interaction. 


\section{Glutamic Acid Decarboxylase (GAD) Autoantibodies}

In an earlier seminal report, incubation of rat islets with radioactively labeled $\left[{ }^{35} \mathrm{~S}\right]$-methionine and subsequent immunoprecipitation of solubilized membranes with serum from newly diagnosed patients with T1D or controls showed that an antigen with a molecular weight of $64 \mathrm{kDa}$ was precipitated by sera from T1D patients (Baekkeskov et al. 1989). The antibodies to this 64 -kDa antigen were present in $~ 80 \%$ of new onset patients and in pre-diabetics before the appearance of clinical disease. The nature of the $64-\mathrm{kDa}$ antigen remained unknown until the report by Solimena et al. (1988) showing autoantibodies to GABA-ergic neurons and pancreatic $\beta$ cells in an unusual condition termed Stiff Man syndrome. Glutamic acid decarboxylase is the enzyme that catalyzes the conversion of glutamic acid to gamma amino butyric acid (GABA), a potent inhibitory neurotransmitter. This led Baekkeskov et al. (1990) to rapidly identify GAD as the $64-\mathrm{kDa}$ autoantigen in T1D (Karlsen et al. 1991; Atkinson et al. 1993). Other molecular-related forms of GAD, such as the $67-\mathrm{kDa}$ isoform, have subsequently been identified (Hagopian et al. 1993). Autoantibodies against GAD are a predictor of progression to overt diabetes. When coupled with insulin autoantibodies and islet cell antibodies (ICA), their ability to predict the likelihood of developing T1D in asymptomatic first-degree relatives of T1D patients is quite high.

\section{IA-2 (ICA512) Autoantibodies}

The neuroendocrine antigen IA-2 (ICA512) is a major autoantigen in T1D (Lan et al. 1994). It is an enzymatically inactive member of the tyrosine phosphatase family, involved in regulating insulin secretion. Assessment of the presence of IA-2 autoantibodies contributes to the predictability of the likelihood of developing T1D. As shown by Verge et al. (1996) and others (Pietropaolo et al. 2002; Achenbach et al. 2004), ICA512 (IA-2) and its homolog IA-2 $\beta$ (phogrin) are both neuroendocrine molecules. The deduced ICA512(IA-2) cDNA sequence reveals a 979- amino-acid protein with a single transmembrane region and with significant homology to the receptor-type PTP(RT-PTPase). A PTP homolog, termed phogrin, was subsequently identified. Subcellular fractionation of insulinoma tissue showed that both IA-2 and phogrin had a very similar cellular distribution to that of insulin and carboxypeptidase $\mathrm{H}$, and these two molecules are predominantly localized in the secretory granules of neuroendocrine cells (Wasmeier and Hutton 1996; Mziaut et al. 2006).

Although the main immune reactive region of the IA-2 molecule was thought to reside within its intracellular domain (amino acids 601979), the inclusion of this region together with other reactive epitope regions of the molecule (encompassing amino acid residues 256-979) has permitted the development of highly accurate constructs to assess the presence of antibodies against IA-2 (Kawasaki et al. 1997). However, other research has also suggested that humoral autoimmunity against the intracellular domain of the molecule is related to a high risk of faster T1D development (Fig. 2) (Morran et al. 2010).

\section{Zinc Transporter Family Member 8 (ZnT8) Autoantibodies}

ZnT8 is a member of the cation diffusion facilitator family, with abundant expression in pancreatic $\beta$ cells, although it is also expressed in extra-pancreatic tissues (Chimienti et al. 2004; Wijesekara et al. 2009). In the $\beta$ cell, it plays an important physiological role because $\mathrm{Zn}$, which is highly concentrated in $\beta$ cells, is needed for normal insulin storage. $\beta$-Cell-specific deletion of ZnT8 in mice results in glucose intolerance, reduced $\beta$-cell zinc accumulation, and anomalous insulin granules, as well as blunted firstphase glucose-stimulated insulin secretion, reduced insulin-processing enzyme transcripts, and increased pro-insulin levels (Wijesekara et al. 2010). Its relevance as an important T1D autoantigen was first described by Wenzlau et al. (2007), following an evaluation of 68 candidate islet autoantigens compiled from multidimensional analyses of microarray mRNA expression profiling. The assessment of the zinc transporter ZnT8 (Slc30A8 encodes ZnT8) indicated that 
M. Pietropaolo et al.

A

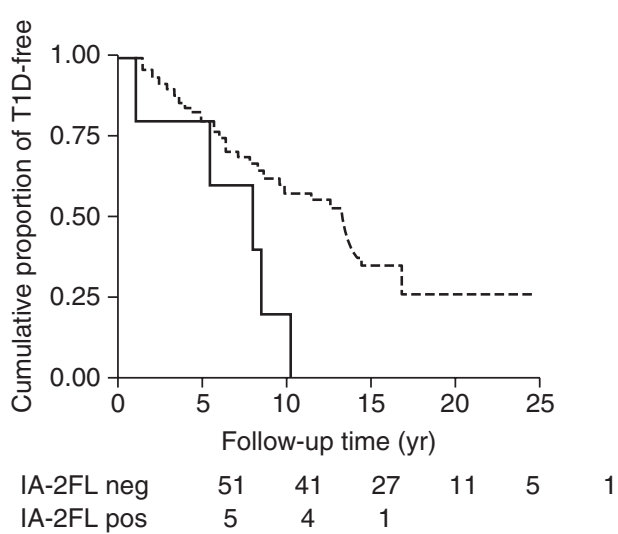

B

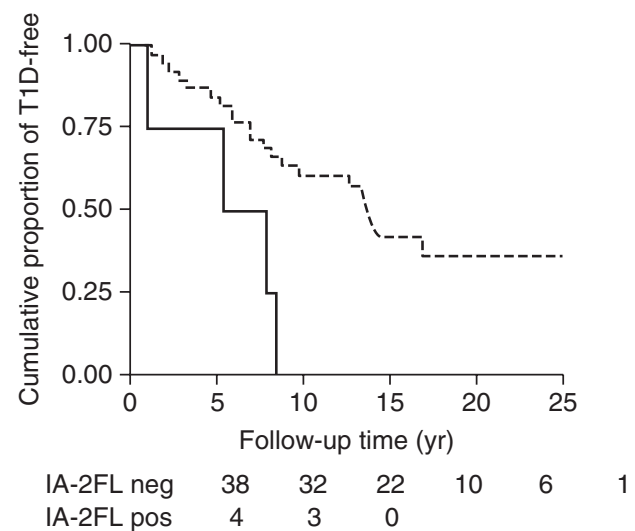

Figure 2. (A) The rate of progression to T1D development in relatives negative for ICA512bdc carrying GAD65 in the absence (dashed line) or presence (solid line) of autoantibodies reacting with IA-2 full-length (IA-2FL) (amino acids $1-979)$ ( $\log$ rank, $P=0.016)$. In this subgroup of relatives, the cumulative risk of developing insulin-requiring diabetes in IA-2 full-length antibody-positive FDR was strikingly high, being $100 \%$ by 11 yr of follow-up in GAD65 antibody positives ( $\log$ rank, $P=0.026$ ). (B) This effect was also observed in FDR selected for being negative for ICA512bdc having at least two islet autoantibodies in the absence (dashed line) or presence (solid line) of autoantibodies reacting with IA-2 full length (IA-2FL) (amino acids 1-979) (log rank, $P=$ 0.003 ). In these relatives, the cumulative risk of progressing to overt diabetes was $100 \%$ by $10 \mathrm{yr}$ of follow-up (log rank, $P=0.022$ ). (Figure is from Morran et al. 2010; reprinted, with permission, from The Endocrine Society (C) 2010.)

it was targeted by autoantibodies in $60 \%-80 \%$ of new-onset T1D compared with $<2 \%$ of healthy controls, $<3 \%$ type 2 diabetic patients, and in up to $30 \%$ of patients with other T1Dassociated autoimmune pathologies. Interestingly, ZnT8 antibodies were found in $26 \%$ of T1D subjects who had not shown antibody positivity to other commonly measured autoantigens such as glutamate decarboxylase (GAD), protein tyrosine phosphatase IA-2 (IA2), insulin (I), or in the assay for cytoplasmic islet cell antibodies (ICA). Further research has revealed polymorphisms in ZnT8 that are relevant to its role as a major T1D autoantigen. There are three polymorphic variants located in the intracellular (carboxyl terminus) domain of the transporter protein, namely, Arg-325, Trp-325, and Gln-325. Of these variants, Trp-325 (W) and Arg-325 (R) have been shown to be the major autoantigenic polymorphisms in T1D, and use of a construct containing the $\mathrm{W}$ and $\mathrm{R}$ variants (ZnT8WR) (Wenzlau et al. 2008) has proven its efficacy as a screen for T1D-associated humoral autoimmunity. More recently, a chimeric construct containing amino acid residues 609979 of the intracellular domain of IA2, linked to peptides containing both $\mathrm{ZnT} 8 \mathrm{~W}$ and $\mathrm{R}$ polymorphisms, has been successfully developed and tested as a broader and more economical screen to detect patients showing humoral autoimmunity against IA-2 and/or ZnT8 (Yu et al. 2010).

\section{CONNECTING GENETICS WITH AUTOANTIBODIES}

Type 1 diabetes is a complex polygenic disease for which there is a small number of genes with large effects (i.e., HLA) and a large number of genes with small effects (Todd et al. 2007; Barrett et al. 2009). Risk of T1D progression is conferred by specific HLA DR/DQ alleles (e.g., DRB1*03-DQB1*0201 [DR3] or DRB1* 04-DQB1*0302 [DR4]) (Eisenbarth 2007). In addition, HLA alleles such as DQB1*0602 are associated with dominant protection from T1D in multiple populations (Pugliese et al. 1999). 
It is commonly accepted that HLA typing is not the optimal primary screening tool for T1D, and it is not sufficient alone to predict the disease onset. However, HLA genotyping in firstdegree relatives of T1D probands can be useful. Aly et al. (2006) reported that risk for islet autoimmunity drastically increased in DR3/4DQ2/DQ8 siblings who shared both HLA haplotypes identical by descent with their diabetic proband sibling ( $63 \%$ by age 7 , and $85 \%$ by age 15) as compared with siblings who did not share both HLA haplotypes with their diabetic proband siblings (Fig. 3). These data indicate that HLA genotyping at birth may identify individuals at very high risk of developing T1D, before the occurrence of clear signs of humoral autoimmunity and eventually overt disease. In addition, we previously identified a phenotype in subjects with high-risk HLADQ haplotypes who remained seronegative for islet autoantibodies even after significant length of followup during progression to the insulin-requiring T1D (Pietropaolo et al. 2002). Finally, in a more recent study, Howson et al. (2011) examined the relationships between the presence of GAD and IA-2 autoantibodies with HLA genes and 3779 single-nucleotide polymorphisms (SNPs) in 2531 subjects with childhood-onset T1D. The results of this comprehensive assessment indicated that GAD autoantibodies were associated primarily with HLA-DQB1. For IA-2 autoantibodies, the strongest association was with HLADRB1. However, there was no association between the presence of antibodies against either IA-2 or GAD and the T1D high-risk genotype, HLA-DRB $1^{*} 03 / 04$, although surprisingly, there was an association of IA-2 autoantibody positivity with the T1D-protective allele HLADQB $1^{*} 030$. These results overall suggest that the presence of high-genetic-risk HLA haplotypes and the presence of islet autoantibodies do not necessarily follow an obligate correlation in the development of autoimmune T1D.

\section{CLINICAL APPLICATIONS}

\section{Relevance as Predictors of Risk for T1D, Role of Age and Specificity}

Combining both immunological and metabolic strategies (e.g., oral glucose tolerance test or the
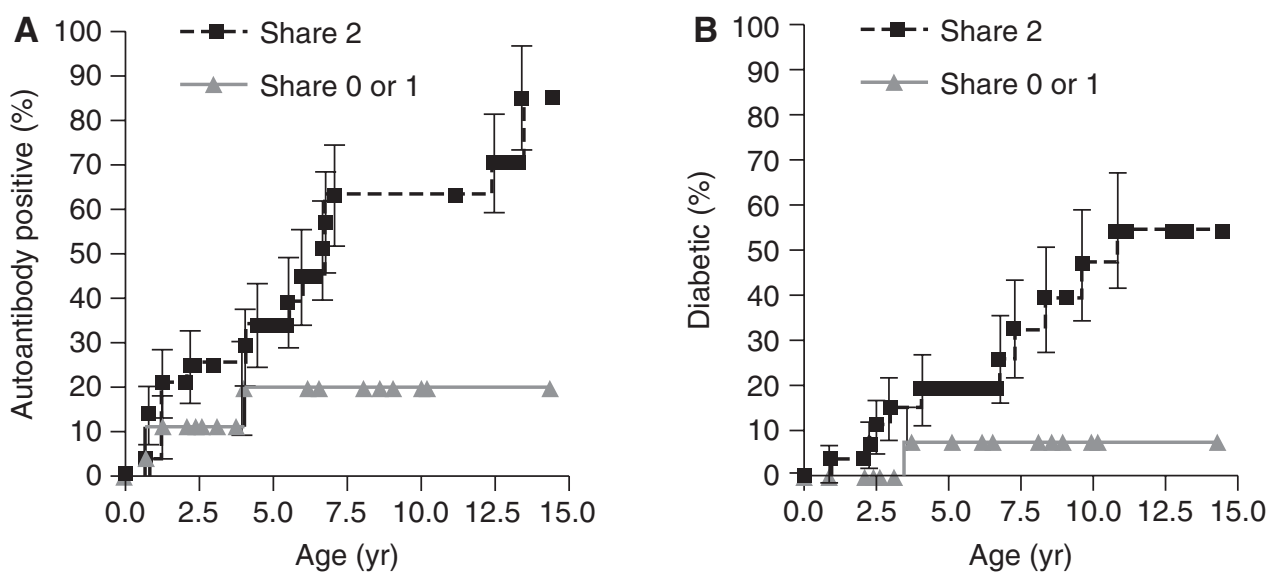

$\begin{array}{lllllll}\text { Share 2: } 29 & 20 & 14 & 7 & 7 & 5 & 2 \\ \begin{array}{l}\text { Share 0 } \\ \text { or 1: }\end{array} \quad 19 & 15 & 10 & 7 & 3 & 2 & 2\end{array}$

\begin{tabular}{|c|c|c|c|c|c|}
\hline $\begin{array}{l}\text { Share 2: } 29 \\
\text { Share 0 }\end{array}$ & 24 & 17 & 11 & 8 & 6 \\
\hline or 1: 19 & 17 & 12 & 8 & 0 & \\
\hline
\end{tabular}

Figure 3. Haplotype sharing survival curves. Shown is progression to anti-islet autoimmunity $(A)$ and type $1 \mathrm{~A}$ diabetes $(B)$ in DR3/4-DQ8 siblings stratified by the number of HLA haplotypes shared with their proband siblings. $n=48$ for $A$ and $B$; error bars for all panels represent the SEM. (Figure from Aly et al. 2006; reprinted, with permission, from National Academy of Sciences (C) 2006.) 
M. Pietropaolo et al.

first-phase $[1+3 \mathrm{~min}]$ insulin response of an intravenous glucose tolerance) is helpful, the current opinion is that type 1 diabetes progression can be predicted with $80 \%-100 \%$ accuracy within 5-and 10-yr follow-up, respectively (Xu et al. 2010).

A study on the Diabetes Autoimmunity Study in the Young (DAISY) cohort showed that $89 \%$ of children who progressed to T1D had two or more islet-related autoantibodies (Steck et al. 2011). Importantly, age of diagnosis of diabetes was strongly correlated with age of appearance of first autoantibody and IAA levels. By life-table analysis (Fig. 4A), children exhibiting two or more autoantibodies showed a nearly linear progression to diabetes $(P<0.0001)$. Children with persistently positive IAA levels had a higher progression rate to overt T1D ( $100 \%$ by $5.6 \mathrm{yr}$ ) as compared with children with fluctuating IAA levels $(63 \%$ by the $10-y r$ follow-up; $P<0.0001$ ) (Fig. 4B). Finally, in children enrolled in the DAISY study followed to the development of diabetes onset, only high IAA titer correlated with rapid progression to T1D
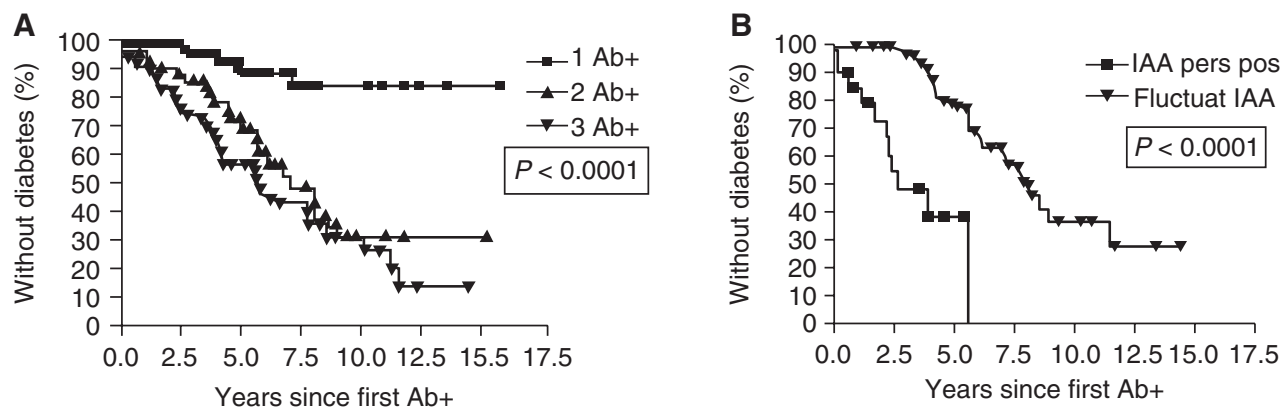

$1 \mathrm{Ab}+N=74 \quad 55 \quad 26 \quad 13 \quad 8 \quad 3 \quad 1$

$2 \mathrm{Ab}+N=47 \quad 39 \quad 19 \quad 10 \quad 3 \quad 1$

$3 \mathrm{Ab}+N=48 \quad 33 \quad 20 \quad 11 \quad 6 \quad 1$

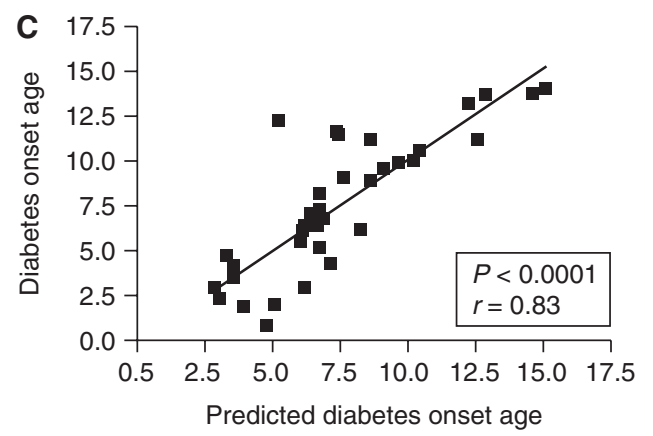

Diabetes predicted age $=-0.6-1.0^{*} \log$ (initial IAA) $+0.9^{\star}$ initial $\mathrm{Ab}$ number $+1.1^{*}$ age first $\mathrm{Ab}+$

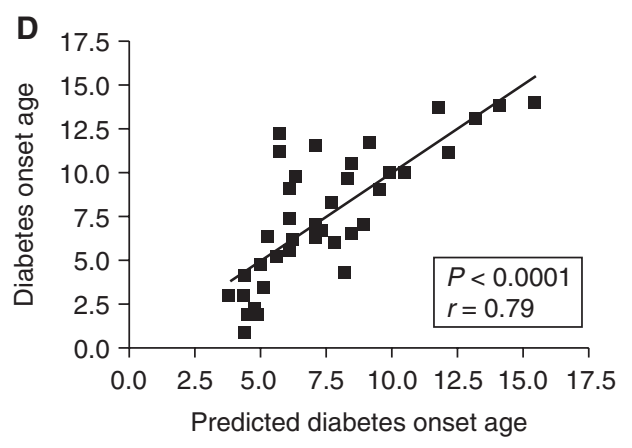

IAA pers pos $N=20 \quad 92$

Fluctuat IAA $N=68 \quad 61 \quad 33 \quad 17 \quad 7 \quad 2$

Diabetes predicted age $=$ 2.6-1.3* $\log \left(\right.$ mean IAA) $+0.8^{*}$ age first $A b+$

Figure 4. (A) Progression to diabetes in children positive for anti-islet autoantibodies $(n=169)$. There was no significant difference in the progression rate between subjects with two or three positive antibodies. (B) Progression to diabetes in children with persistently positive IAA levels and fluctuating IAA levels $(n=88)$. (IAA pers pos) Persistently positive IAA levels; (Fluctuat IAA) fluctuating IAA levels. ( $C$ ) Predicted age of diagnosis of diabetes (initial IAA, GAD, and IA-2 levels; $n=38$ ). Analyses performed in all subjects who had their first antibody measurement before $1.5 \mathrm{yr}$ and progressed to diabetes. $(D)$ Predicted age of diagnosis of diabetes (mean IAA, GAD, and IA-2 levels; $n=38$ ). Analyses performed in all subjects who had their first antibody measurement before $1.5 \mathrm{yr}$ and progressed to diabetes. (Figure from Steck et al. 2011; reprinted, with permission, from the American Diabetes Association (C) 2011.) 
onset (Fig. 5) $(P<0.0001)$. As a matter of fact, this effect was not evident with respect to the presence of high GAD65 or IA-2/ICA512 autoantibody titer (Fig. 6). Therefore, insulin autoantibody levels at the time of diagnosis are inversely related to the age of the patient, being highest in those $<5 \mathrm{yr}$ of age, and hence, IAAs appear to be an early marker of $\beta$-cell destruction. The titer of insulin autoantibodies along with the insulin secretory response judged by the first-phase insulin levels at 1 and 3 min after an intravenous glucose challenge, has also been successfully used to construct mathematical models to predict the likelihood of clinical diabetes in asymptomatic first-degree relatives of patients (Eisenbarth 1986). Investigators from the DAISY study reported that five children were found to have persistent IAAs before $1 \mathrm{yr}$ of age, and four of them went on to develop the clinical onset of T1D (all before $3.5 \mathrm{yr}$ of age). In contrast, children not exhibiting persistent IAAs before the age of $1 \mathrm{yr}$ rarely rapidly developed an insulin requirement. When analyzing only children followed from birth who progressed to diabetes, the two major predictors of age of diabetes diagnosis were the age at which autoantibodies first appeared and the mean level of insulin autoantibodies (Fig. 4A,B). These observations emphasize the utility of IAAs, particular-

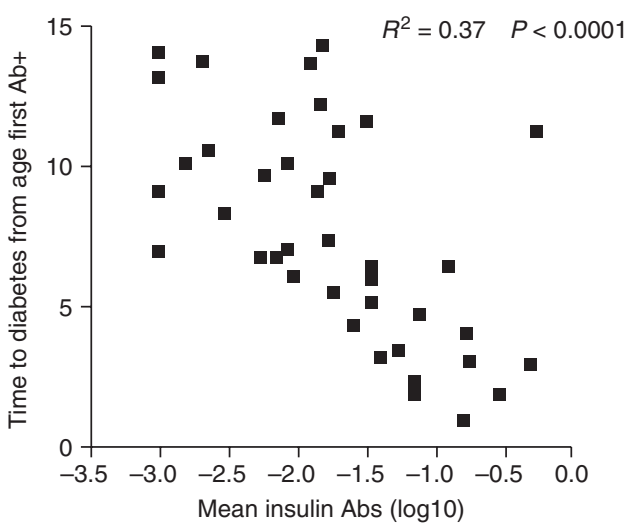

Figure 5. Mean log IAA versus time to diabetes progression in first-degree relatives of T1D probands. In these children from the DAISY study followed to the development of diabetes onset, high IAA levels correlated with rapid progression to T1D onset.
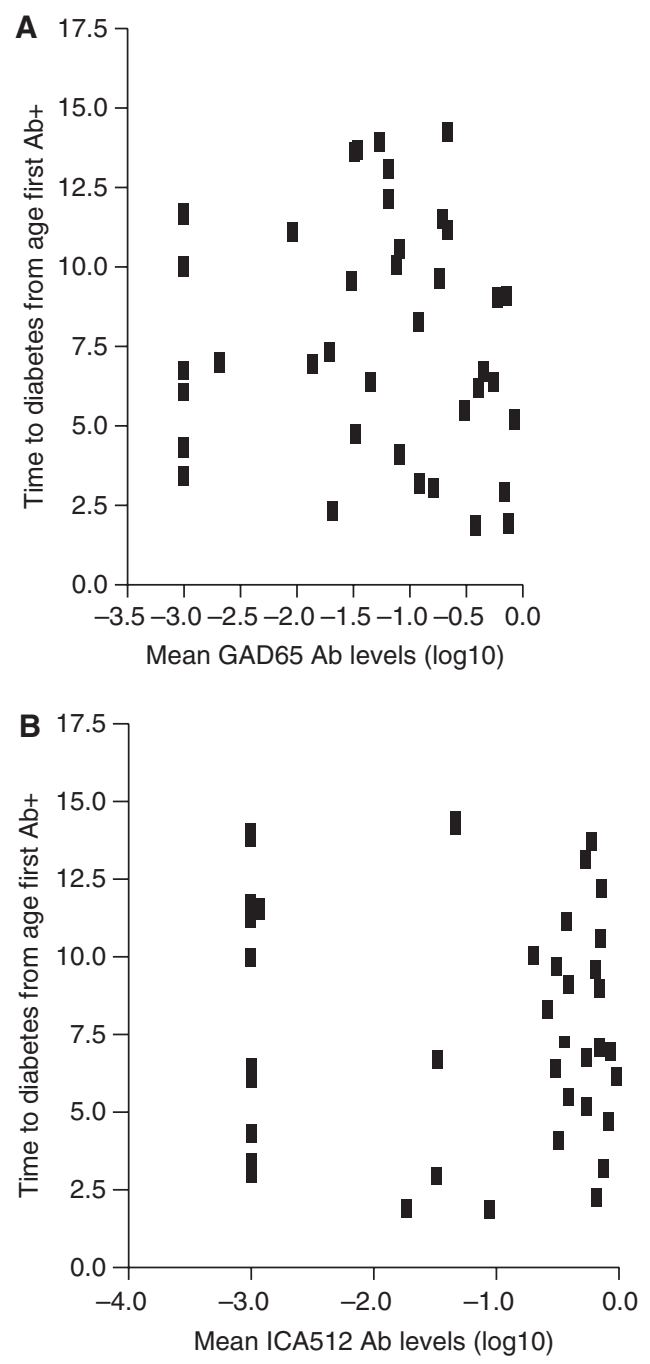

Figure 6. (A) GAD65, and (B) IA-2/ICA12 antibody titers in children from the DAISY study followed to the development of diabetes onset. There is no correlation with high GAD65 or IA-2/ICA512 titers and rapid progression to diabetes.

ly in younger populations, and justify the need to design trials focused on such a young group. However, the success of these strategies depends on the safety and effectiveness of therapeutic regimens. Indeed, this was the strategy in the trial to prevent development of T1D (DPT-1) that successfully predicted the development of diabetes in first-degree relatives of T1D patients (Skyler et al. 2001). 
M. Pietropaolo et al.

\section{Detection of Novel Forms and Subgroups of Diabetes, the LADA Example}

Although the detection of islet autoantibodies is overall the major diagnostic hallmark of autoimmune T1D risk assessment and progression, the ability to detect these autoantibodies has also allowed the characterization of unique subpopulations of the disease, with evident implications for therapeutic strategies. The specific characterization of the diverse subtypes of diabetes has been a dynamic field of research and an active area of discussion. Awell-documented example is the case of patients who are generally adults, who present a type 2 diabetes phenotype as well as circulating islet autoantibodies (Zimmet et al. 1994). These characteristics are defined as Latent Autoimmune Diabetes of Adults (LADA) and sometimes are termed type $1.5 \mathrm{di}-$ abetes (Palmer and Hirsch 2003). The immunological diagnosis of LADA relies primarily on the detection of autoantibodies against GAD65 in the serum of clinically diagnosed T2D patients who also show impaired insulin secretion and a high frequency of being on insulin treatment. Additionally, it has been previously reported that LADA patients possess T cells reactive to islet proteins as is also the case in "canonical" type 1 diabetes, in contrast to classic autoantibody-negative T2D patients (Brooks-Worrell et al. 2011).

The presence of GAD65 and/or IA-2 autoantibodies in T2D patients diagnosed by conventional criteria (ADA or WHO) is not uncommon among older diabetics, being 5\%$10 \%$ or higher, especially in those on insulin therapy (Barinas-Mitchell et al. 2004, 2006; Leslie et al. 2006; Pietropaolo et al. 2007). Thus, there may be as many GAD65 antibody-positive older diabetics as there are children affected by T1D. This is not a trivial issue. Moreover, additional immunological markers of autoimmune diabetes might identify even a larger sample of clinically diagnosed T2DM patients. Given its relative simplicity, testing for GAD65 and IA-2 autoantibodies should be part of the diagnostic assessment for clinically diagnosed T2D because it might predict the rate of progression to insulin requirement in older populations. Those found to be GAD65 antibody-positive are prob- ably candidates for early insulin therapy or more aggressive oral therapies to lower their glycohemoglobin levels. Clinical trials and epidemiological observational studies should clearly separate GAD65 antibody-positive older diabetics from those who are GAD65 antibody-negative.

\section{Relationship with Other Autoimmune Diseases (Altered Antigens)}

During immune system development, lymphocytes that react to self-antigens in the thymus and bone marrow are deleted. However, host molecules, in particular proteins and nucleic acids, are constantly being modified in the course of normal physiological events. A key posttranslational modification in autoimmunity appears to be the citrullination of arginine amino acid residues, by the enzymatic deimination of arginine to citrulline (Eggleton et al. 2008; Doyle and Mamula 2012). This reaction is catalyzed by the enzyme peptidyl arginine deiminase (PAD) (Soderlin et al. 2004). In multiple sclerosis and RA, citrullinated isoforms of myelin basic protein (Moscarello et al. 2007) and fibrin (Masson-Bessiere et al.2001) have been found in the brain and synovia, respectively. It must be pointed out that the detection of anti-citrullinated protein antibodies (ACPA) has proven extremely useful in the early diagnosis and assessment of prognosis in rheumatoid arthritis (RA) and has also led to insights into gene environment effects in autoimmune disease (Kastbom et al. 2004).

With regard to $\mathrm{T} 1 \mathrm{D}$, processing of molecules such as insulin within the $\beta$ cell generates peptides that are then taken up by APCs either as whole dead $\beta$ cells or specifically granules of $\beta$ cells for eventual further processing/presentation of islet peptides to self-reactive $\mathrm{T}$ cells (Fig. 1) (Crawford et al. 2011). Furthermore, Stadinski et al. (2010) have shown that chromogranin A (ChgA) is an autoantigen in T1D (Table 1), and that the peptide WE14 from ChgA stimulates diabetogenic $\mathrm{CD} 4{ }^{+} \mathrm{T}$-cell clones. The natural form of the antigen in $\beta$-cell extracts is far more potent than an unmodified synthetic WE14 peptide, suggesting that this peptide may be posttranslationally modified with a carbonyl group in murine pancreatic islets. 
It is quite possible that the number of reported altered neo-antigens will increase in T1D, because the attendant hyperglycemic and prooxidative metabolic milieu includes abnormal glycosylations and oxidative damage to proteins. The latter are processes that affect autoantigenic proteins in other diseases such as RA and SLE, and thus provide a conceptual relationship of diabetes with other autoimmune diseases with respect to autoantigenesis.

How Do Autoantibody Specificities Relate to T-Cell Response and T-Cell Specificity?

A widening body of both basic and clinical investigations has tried to address the relationship between islet autoantibodies and the activation of $\mathrm{T}$ cells by cognate autoantigens in T1D. An early report was a study by Keller (1990), who described proliferative responses to human insulin in T-lymphocytes during the peri-diabetic period, in a significant proportion (67\%) of ICA-positive, first-degree relatives of T1D patients who had never been treated with insulin, whereas in contrast, none of the controls showed the proliferative effect. Interestingly, the $\mathrm{T}$-cell responses were not correlated with levels of insulin autoantibodies. Similarly, studies addressing other islet autoantigens by Atkinson et al. (1992) reported that there was a higher likelihood of a proliferative response to GAD in peripheral-blood mononuclear cells from patients with T1D and in relatives positive for ICA, compared with that seen in healthy controls and ICA-negative relatives of the patients. Other T1D-associated autoantigens targeted by humoral autoimmunity have also been shown to stimulate $\mathrm{T}$ cells, such as the cases of T-cell proliferation in response to IA-2 (DurinovicBellò et al. 1996; Roep et al. 1996; Reijonen et al. 2004). More recently, cellular immunoblot, U.K.-ELISPOT, and T-cell proliferation assays seemed to distinguish responses from patients with type 1 diabetes and healthy control subjects (Herold et al. 2009). Albeit many attempts have been made, the demonstration in the clinical setting of the relationship between $\mathrm{T}$ cell and autoantibody responses is difficult for at least the following reasons: (1) The frequency of antigen-specific autoreactive $\mathrm{CD} 4^{+} \mathrm{T}$ cells is very low in peripheral blood. (2) There might be variability in their appearance in peripheral blood. (3) The methodologies to detect these $\mathrm{T}$ cells can be laborious (i.e., some methodologies require expansion of $\mathrm{CD}^{+}{ }^{+} \mathrm{T}$ cells with antigen for up to $10 \mathrm{~d}$ ). (4) There is very a high degree of variability inherent to T-cell proliferation assays.

\section{Does Ig Isotype Matter?}

It is well known that pro-inflammatory antibodies of the human IgG1 and IgG3 subclass can cause complement activation, attract lymphocytes to the target organ, and are used as surrogate markers of disease activity (Gomez et al. 2010). In T1D, a study investigating Ig isotypes against insulin, assessed insulin autoantibody (IAA) isotypes in children who were at genetic risk of T1D and encompassed IAA-positive children who progressed to T1D as well as nonprogressor infants (Hoppu et al. 2004a). In this study, it was found that children who progressed rapidly to T1D showed strong IgG1 and IgG3 immunoreactivity to insulin, in contrast to a weak or absent IgG3 response, which was deemed to confer relative protection. Hoppu et al. (2004b) examined progression to onset, among non-diabetic first-degree relatives of children with T1D and found the GAD65 isotype response, and concluded that the detection of isotypes against GAD65 could not reliably discriminate progressors from non-progressors to diabetes onset among antibody-positive siblings of children with T1D.

In summary, the characterization of autoantibody isotypes against the islet autoantigens in the estimation of T1D risk has revealed a diversity of results that need a body of confirmatory reports before a consensus can be achieved on their applicability for clinical practice.

\section{EVIDENCE FOR INVOLVEMENT OF B-LYMPHOCYTES AND AUTOANTIBODIES IN PATHOGENESIS}

An accurate account of the relevance of B cells in autoimmune diabetes was shown earlier in 
M. Pietropaolo et al.

seminal studies using the NOD mouse to generate B-lymphocyte-deficient mice (Hanson et al. 1996) and also through the use of monoclonal antibodies to deplete the population of $B$ cells (Noorchashm et al. 1997). In these studies, the inhibition of B cells resulted in the concomitant inhibition of insulitis. The physiological significance and potential clinical relevance of these early studies have now been validated and underscored by the use of an anti-CD20 antibody (rituximab) proved highly promising not only in the treatment of T1D but also in other autoimmune disorders that are oftentimes coincident with T1D, such as autoimmune thyroiditis and Stiff Person syndrome, in which high-titer GAD autoantibodies are a diagnostic identifier (Dupond et al. 2010). The use of rituximab in human clinical trials has also stimulated the interest in B-cell antigen capture and presentation in T1D, particularly following the results of the rituximab trial in newly diagnosed T1D patients showing delay in disease progression, associated with transient B-cell depletion (Pescovitz et al. 2009). These observations in humans are reinforced by studies in NOD mice using specific mAbs for CD20 (Xiu et al. 2008) and by in vivo neutralization of the Blymphocyte stimulator (BLyS/BAFF), which in both cases prevented autoimmune diabetes progression 1 (Zekavat et al. 2008). Interestingly, long-term in vivo BLyS neutralization also led to reduction of IAA titers. This effect in antiBLyS-treated NOD mice also correlated with a restoration of $\operatorname{Ig} \lambda$ clonotype negative selection at the lymphopenic transitional B-cell compartment $(\mathrm{TR}) \rightarrow$ splenic follicle ( $\mathrm{TR} \rightarrow \mathrm{FO}$ ) checkpoint. This is a defect, which has been delineated as an aberrant characteristic of Blymphocyte homeostasis in NOD mice (Zekavat et al. 2008). These data collectively suggest that long-term in vivo BLyS neutralization is capable of correcting a defect in NOD B-cell tolerance by increasing the stringency of negative selection at the TR $\rightarrow$ FO checkpoint. Two recent reports have shed additional light on the broad physiological meaning of B-cell inhibition in autoimmune diabetes by anti-CD20 therapy, because the study showed that rituximab differentially inhibited anti-islet autoanti- bodies in T1D patients, and it blocked IAA for $>1 \mathrm{yr}$, in insulin-treated patients (Yu et al. 2011). Finally, the murine CD20-specific 18B12 antibody that, like rituximab, depletes the follicular (FO) but not marginal zone subset of B cells (MZB), efficiently inhibited diabetes development in NOD mice in a likely regulatory T-celldependent manner only when treatment was initiated before IAA detection. The latter observations suggest that MZBs, which are known to be potent APCs, may well play a role in the chain of events leading to overt diabetes (Serreze et al. 2011).

\section{Potential Role of Humoral Autoimmunity in Non- $\beta$-Cell Tissues}

Humoral autoimmunity in T1D has been shown to target pancreatic nervous system tissue structures, suggesting the possibility that non$\beta$-cell elements can elicit immune responses in T1D (Rabinowe et al. 1989; Winer et al. 2003; Louvet et al. 2009). One of these molecular targets seems to be peripherin (Boitard et al. 1992). This molecule is expressed in multiple endocrine tissues, including nerve fibers surrounding islets of Langerhans in the pancreas, adrenal medulla, nerve fibers in interstitial tissue between thyroid follicles, and nerve fibers adjacent to ovarian follicles (Chamberlain et al. 2010). Serologic responses to peripherin have been found in autonomic fibers in the pancreas, thyroid, and ovary, supporting clinical observations indicating that neuronal elements may be a molecular target for immune-mediated injury in multiple forms of endocrine autoimmunity, including T1D (Chamberlain et al. 2010). However, it remains to be established as to whether or not the presence of peripherin antibodies, along with serologic responses to other putative neuronal elements, are predictive for the development of small fiber neuropathy (autonomic and/or somatic) and for the progression to overt diabetes.

Although the presence of these autoantibodies reacting with neuronal tissues is thoughtprovoking and may somehow play a role in the pathophysiology of a subset of diabetic neuropathy, definite data establishing their role as 
Humoral Autoimmunity in Type 1 Diabetes

causal factors remains elusive (Ejskjaer et al. 1998). The examination of inflammatory responses in peripheral and autonomic nervous structures is becoming a growing area of investigation.

\section{CONCLUDING REMARKS}

Type 1 diabetes results from autoimmune destruction/dysfunction of pancreatic $\beta$ cells. In physiological conditions, there is balance between pathogenic $\mathrm{T}$ cells that mediate disease such as $\mathrm{T}$ cells with marked conservation of their TCRs (e.g., insulin), and regulatory cells that control autoimmunity (Bluestone et al. 2010). In T1D and other autoimmune disorders, there is an altered balance between pathogenic and regulatory $\mathrm{T}$ cells.

Autoantibodies are some of the most potent risk determinants for autoimmune diseases such as T1D with an estimated relative risk exceeding 100\%. The archetypical model for the application of autoantibodies in disease prediction is T1D. Humoral bioassays have achieved a high degree of accuracy and sophistication to allow the design of algorithms for inclusion of individuals at risk of developing T1D in clinical trials around the world. In particular, seminal studies have suggested that using a combination of humoral immunological markers gives a higher predictive value for T1D progression, and greater sensitivity, without significant loss of specificity. There is a growing effort and a large opportunity for exploring novel strategies alone or in combination with immunomodulation with the ultimate goal to find the cure for T1D. Development of therapies targeting specific B-lymphocytes is underway in animal models of autoimmune diabetes and eventually may be examined in humans. Even though the possible pathogenic role of islet-associated autoantibodies has not been elucidated, the list of useful biomarkers such as autoantigen-specific $\mathrm{CD}^{+}{ }^{+}$and $\mathrm{CD}^{+}$effectors, memory and regulatory $\mathrm{T}$ cells related to disease pathogenesis (Khadra et al. 2011), and their relationship with the relevance of cognate autoantibodies will continue to expand.

\section{ACKNOWLEDGMENTS}

This work is supported by the National Institutes of Health grants R01 DK53456, DK56200, NIDDK PA-04-081 (to M.P.) and National Institutes of Health grants R37-DK32493, DK 320083, DK050979, DK57516, AI050864, and N01-AI15416 (to G.E.). We greatly acknowledge the Brehm Coalition for its support.

\section{REFERENCES}

Achenbach P, Warncke K, Reiter J, Naserke HE, Williams AJ, Bingley PJ, Bonifacio E, Ziegler AG. 2004. Stratification of type 1 diabetes risk on the basis of islet autoantibody characteristics. Diabetes 53: 384-392.

Allen JS, Pang K, Skowera A, Ellis R, Rackham C, LozanoskaOchser B, Tree T, Leslie RD, Tremble JM, Dayan CM, et al. 2009. Plasmacytoid dendritic cells are proportionally expanded at diagnosis of type 1 diabetes and enhance islet autoantigen presentation to T-cells through immune complex capture. Diabetes 58: 138-145.

Aly TA, Ide A, Jahromi MM, Barker JM, Fernando MS, Babu SR, Yu L, Miao D, Erlich HA, Fain PR, et al. 2006. Extreme genetic risk for type 1A diabetes. Proc Natl Acad Sci 103: 14074-14079.

Atkinson MA, Eisenbarth GS. 2001. Type 1 diabetes: New perspectives on disease pathogenesis and treatment. Lancet 358: 221-229.

Atkinson MA, Kaufman DL, Campbell L, Gibbs KA, Shah SC, Bu D-F, Erlander MG, Tobin AJ, Maclaren NK. 1992. Response of peripheral-blood mononuclear cells to glutamate decarboxylase in insulin-dependent diabetes. Lancet 339: 458-459.

Atkinson MA, Kaufman DL, Newman D, Tobin AJ, Maclaren NK. 1993. Islet cell cytoplasmic autoantibody reactivity to glutamate decarboxylase in insulin-dependent diabetes. J Clin Invest 91: 350-356.

Baekkeskov S, Warnock G, Christie M, Rajotte RV, Larsen PM, Fey S. 1989. Revelation of specificity of 64K autoantibodies in IDDM serums by high-resolution 2-D gel electrophoresis: Unambiguous identification of $64 \mathrm{~K}$ target antigen. Diabetes 38: 1133-1141.

Baekkeskov S, Aanstoot H, Christgau S, Reetz A, Solimena MS, Cascalho M, Folli F, Richter-Olsen H, DeCamilli P. 1990. Identification of the $64 \mathrm{~K}$ autoantigen in insulin dependent diabetes as the GABA-synthesizing enzyme glutamic acid decarboxylase. Nature 347: 151-156.

Barinas-Mitchell E, Pietropaolo S, Zhang YJ, Henderson T, Trucco M, Kuller LH, Pietropaolo M. 2004. Islet cell autoimmunity in a triethnic adult population of the $\mathrm{Na}$ tional Health and Nutrition Examination Survey (NHANES) III. Diabetes 53: 1293-1302.

Barinas-Mitchell E, Kuller LH, Pietropaolo S, Zhang YJ, Henderson T, Pietropaolo M. 2006. The prevalence of the 65-kilodalton isoform of glutamic acid decarboxylase autoantibodies by glucose tolerance status in elderly patients from the cardiovascular health study. J Clin Endocrinol Metab 91: 2871-2877. 
M. Pietropaolo et al.

Barrett JC, Clayton DG, Concannon P, Akolkar B, Cooper JD, Erlich HA, Julier C, Morahan G, Nerup J, Nierras C, et al. 2009. Genome-wide association study and metaanalysis find that over 40 loci affect risk of type 1 diabetes. Nat Genet 41: 703-707.

Bluestone JA, Boehmer H. 2006. Regulatory T cells. Semin Immunol 18: 77.

Bluestone JA, Herold K, Eisenbarth G. 2010. Genetics, pathogenesis and clinical interventions in type 1 diabetes. Nature 464: 1293-1300.

Boitard C, Villa MC, Becourt C, Gia HP, Huc C, Sempe P, Portier MM, Bach JF. 1992. Peripherin: An islet antigen that is cross-reactive with nonobese diabetic mouse class II gene products. Proc Natl Acad Sci 89: 172-176.

Bonifacio E, Atkinson MA, Eisenbarth GS, Serreze DV, Kay TW, Lee-Chan E, Singh B. 2002. International workshop on lessons from animal models for human type 1 diabetes: Analyzing target autoantigens of humoral immunity in nonobese diabetic mice. Ann NY Acad Sci 958: 1-2.

Bonifacio E, Yu L, Williams AK, Eisenbarth GS, Bingley PJ, Marcovina SM, Adler K, Ziegler AG, Mueller PW, Schatz DA, et al. 2010a. Harmonization of glutamic acid decarboxylase and islet antigen-2 autoantibody assays for national institute of diabetes and digestive and kidney diseases consortia. J Clin Endocrinol Metab 95: 3360-3367.

Bonifacio E, Yu L, Williams AK, Eisenbarth GS, Bingley PJ, Marcovina SM, Adler K, Ziegler AG, Mueller PW, Schatz DA, et al. 2010b. Harmonization of glutamic acid decarboxylase and islet antigen-2 autoantibody assays for national institute of diabetes and digestive and kidney diseases consortia. J Clin Endocrinol Metab 95: 3360-3367.

Bottazzo GF, Florin-Christensen A, Doniach D. 1974. Isletcell antibodies in diabetes mellitus with autoimmune polyendocrine deficiencies. Lancet 2: 1279-1282.

Bottazzo GF, Dean BM, McNally JM, Mackay EH, Swift PGF, Gamble DR. 1985. In situ characterization of autoimmune phenomena and expression of HLA molecules in the pancreas in diabetic insulitis. $N$ Engl J Med 313: $353-360$.

Brooks-Worrell BM, Reichow JL, Goel A, Ismail H, Palmer JP. 2011. Identification of autoantibody-negative autoimmune type 2 diabetic patients. Diabetes Care 34: $168-$ 173.

Chamberlain JL, Pittock AJ, Oprescu AM, Dege C, Apiwattanakul M, Kryzer TJ, Lennon VA. 2010. Peripherin-IgG association with neurologic and endocrine autoimmunity. J Autoimmun 34: 469-477.

Chimienti F, Devergnas S, Favier A, Seve M. 2004. Identification and cloning of a $\beta$-cell-specific zinc transporter, ZnT-8, localized into insulin secretory granules. Diabetes 53: 2330-2337.

Crawford F, Stadinski B, Jin N, Michels A, Nakayama M, Pratt P, Marrack P, Eisenbarth G, Kappler JW. 2011. Specificity and detection of insulin-reactive $\mathrm{CD} 4^{+} \mathrm{T}$ cells in type 1 diabetes in the nonobese diabetic (NOD) mouse. Proc Natl Acad Sci 108: 16729-16734.

Di Lorenzo TP, Peakman M, Roep BO. 2007. Translational mini-review series on type 1 diabetes: Systematic analysis of $\mathrm{T}$ cell epitopes in autoimmune diabetes. Clin Exp Immunol 148: 1-16.
Doyle HA, Mamula MJ. 2012. Autoantigenesis: The evolution of protein modifications in autoimmune disease. Curr Opin Immunol 24: 112-118.

Dupond JL, Essalmi L, Gil H, Meaux-Ruault N, Hafsaoui C. 2010. Rituximab treatment of Stiff-Person syndrome in a patient with thymoma, diabetes mellitus and autoimmune thyroiditis. J Clin Neurosci 17: 389-391.

Durinovic-Bellò I, Hummel M, Ziegler AG. 1996. Cellular immune response to diverse islet cell antigens in IDDM. Diabetes 45: 795-800.

Eggleton P, Haigh R, Winyard PG. 2008. Consequence of neo-antigenicity of the "altered self." Rheumatology (Oxford) 47: 567-571.

Eisenbarth GS. 1986. Type I diabetes mellitus: A chronic autoimmune disease. N Engl J Med 314: 1360-1368.

Eisenbarth GS. 2007. Update in type 1 diabetes. J Clin Endocrinol Metab 92: 2403-2407.

Ejskjaer NT, Zanone MM, Peakman M. 1998. Autoimmunity in diabetic autonomic neuropathy: Does the immune system get on your nerves? Diabet Med 15: $723-$ 729.

Gomez AM, Van Den Broeck J, Vrolix K, Janssen SP, Lemmens MA, Van Der Esch E, Duimel H, Frederik P, Molenaar PC, Martinez-Martinez P, et al. 2010. Antibody effector mechanisms in myasthenia gravis-pathogenesis at the neuromuscular junction. Autoimmunity 43: 353370.

Hagopian WA, Michelsen B, Karlsen AE, Larsen F, Moody A, Grubin CE, Rowe R, Petersen J, McEvoy R, Lernmark A. 1993. Autoantibodies in IDDM primarily recognize the $65,000-\mathrm{M}(\mathrm{r})$ rather than the $67,000-\mathrm{M}(\mathrm{r})$ isoform of glutamic acid decarboxylase. Diabetes 42: 631-636.

Hanson MS, Cetkovic-Cvrlje M, Ramiya VK, Atkinson MA, Maclaren NK, Singh B, Elliott JF, Serreze DV, Leiter EH 1996. Quantitative thresholds of MHC class II I-E expressed on hemopoietically derived antigen-presenting cells in transgenic NOD/Lt mice determine level of diabetes resistance and indicate mechanism of protection. J Immunol 157: 1279-1287.

Herold KC, Brooks-Worrell B, Palmer J, Dosch HM, Peakman M, Gottlieb P, Reijonen H, Arif S, Spain LM, Thompson C, et al. 2009. Validity and reproducibility of measurement of islet autoreactivity by T-cell assays in subjects with early type 1 diabetes. Diabetes 58: 2588-2595.

Hoppu S, Ronkainen MS, Kimpimaki T, Simell S, Korhonen S, Ilonen J, Simell O, Knip M. 2004a. Insulin autoantibody isotypes during the prediabetic process in young children with increased genetic risk of type 1 diabetes. Pediatr Res 55: 236-242.

Hoppu S, Ronkainen MS, Kulmala P, Akerblom HK, Knip M. 2004b. GAD65 antibody isotypes and epitope recognition during the prediabetic process in siblings of children with type I diabetes. Clin Exp Immunol 136: $120-128$.

Howson JM, Stevens H, Smyth DJ, Walker NM, Chandler KA, Bingley PJ, Todd JA. 2011. Evidence that HLA class I and II associations with type 1 diabetes, autoantibodies to GAD and autoantibodies to IA-2, are distinct. Diabetes 60: $2635-2644$. 
Husebye ES, Anderson MS. 2010. Autoimmune polyendocrine syndromes: Clues to type 1 diabetes pathogenesis. Immunity 32: 479-487.

Karlsen AE, Hagopian WA, Grubin CE, Dube S, Disteche CM, Adler DA, Barmeier H, Mathewes S, Grant FJ, Foster D, et al. 1991. Cloning and primary structure of a human isoform of glutamic acid decarboxylase from chromosome 10. Proc Natl Acad Sci 88: 8337-8341.

Kastbom A, Strandberg G, Lindroos A, Skogh T. 2004. AntiCCP antibody test predicts the disease course during 3 years in early rheumatoid arthritis (the Swedish TIRA project). Ann Rheum Dis 63: 1085-1089.

Kawasaki E, Yu L, Gianani R, Verge CF, Babu S, Bonifacio E, Eisenbarth GS. 1997. Evaluation of islet cell antigen (ICA) 512/IA-2 autoantibody radioassay using overlapping ICA512/IA-2 constructs. J Clin Endocrinol Metab 82: $375-380$.

Keller RJ. 1990. Cellular immunity to human insulin in individuals at high risk for the development of type I diabetes mellitus. J Autoimmun 3: 321-327.

Khadra A, Pietropaolo M, Nepom GT, Sherman A. 2011. Investigating the role of T-cell avidity and killing efficacy in relation to type 1 diabetes prediction. PLOS ONE 6: e14796.

Kimpimaki T, Kupila A, Hamalainen AM, Kukko M, Kulmala P, Savola K, Simell T, Keskinen P, Ilonen J, Simell O, et al. 2001. The first signs of $\beta$-cell autoimmunity appear in infancy in genetically susceptible children from the general population: The Finnish Type 1 Diabetes Prediction and Prevention Study. J Clin Endocrinol Metab 86: $4782-4788$.

Lan MS, Lu J, Goto Y, Notkins AL. 1994. Molecular cloning and identification of a receptor-type protein tyrosine phosphatase, IA-2, from human insulinoma. DNA Cell Biol 13: 505-514.

Leslie RD, Williams R, Pozzilli O. 2006. Clinical review: Type 1 diabetes and latent autoimmune diabetes in adults: One end of the rainbow. J Clin Endocrinol Metab 91: 16541659.

Louvet C, Kabre BG, Davini DW, Martinier N, Su MA, Devoss JJ, Rosenthal WL, Anderson MS, Bour-Jordan H, Bluestone JA. 2009. A novel myelin P0-specific T cell receptor transgenic mouse develops a fulminant autoimmune peripheral neuropathy. J Exp Med 206: 507-514.

Martin S, Wolf-Eichbaum D, Duinkerken G, Scherbaum WA, Kolb H, Noordzij JG, Roep BO. 2001. Development of type 1 diabetes despite severe hereditary B-lymphocyte deficiency. N Engl J Med 345: 1036-1040.

Masson-Bessiere C, Sebbag M, Girbal-Neuhauser E, Nogueira L, Vincent C, Senshu T, Serre G. 2001. The major synovial targets of the rheumatoid arthritis-specific antifilaggrin autoantibodies are deiminated forms of the $\alpha$ and $\beta$-chains of fibrin 1. J Immunol 166: 4177-4184.

Morran MP, Casu A, Arena VC, Pietropaolo S, Zhang YJ, Satin LS, Nelson P, Omenn GS, Trucco M, Becker DJ, et al. 2010. Humoral autoimmunity against the extracellular domain of the neuroendocrine autoantigen IA-2 heightens the risk of type 1 diabetes. Endocrinology 151: 2528 2537.

Moscarello MA, Mastronardi FG, Wood DD. 2007. The role of citrullinated proteins suggests a novel mechanism in the pathogenesis of multiple sclerosis. Neurochem Res 32: 251-256.

Mziaut H, Trajkovski M, Kersting S, Ehninger A, Altkruger A, Lemaitre RP, Schmidt D, Saeger HD, Lee MS, Drechsel DN, et al. 2006. Synergy of glucose and growth hormone signalling in islet cells through ICA512 and STAT5. Nat Cell Biol 8: 435-445.

Nakayama M, Abiru N, Moriyama H, Babaya N, Liu E, Miao D, Yu L, Wegmann DR, Hutton JC, Elliott JF, et al. 2005. Prime role for an insulin epitope in the development of type 1 diabetes in NOD mice. Nature 435: 220-223.

Noorchashm H, Noorchashm N, Kern J, Rostami SY, Barker CF, Naji A. 1997. B-cells are required for the initiation of insulitis and sialitis in nonobese diabetic mice. Diabetes 46: 941-946.

Palmer JP, Hirsch IB. 2003. What's in a name: Latent autoimmune diabetes of adults, type 1.5, adult-onset, and type 1 diabetes. Diabetes Care 26: 536-538.

Palmer JP, Asplin CM, Clemons P, Lyen K, Tatpati O, Raghu PK, Paquette TL. 1983. Insulin antibodies in insulin-dependent diabetics before insulin treatment. Science 222: 1337-1339.

Peakman M, Stevens EJ, Lohmann T, Narendran P, Dromey J, Alexander A, Tomlinson AJ, Trucco M, Gorga JC, Chicz RM. 1999. Naturally processed and presented epitopes of the islet cell autoantigen IA-2 eluted from HLADR4. J Clin Invest 104: 1449-1457.

Pescovitz MD, Greenbaum CJ, Krause-Steinrauf H, Becker DJ, Gitelman SE, Goland R, Gottlieb PA, Marks JB, McGee PF, Moran AM, et al. 2009. Rituximab, B-lymphocyte depletion, and preservation of $\beta$-cell function. N Engl J Med 361: 2143-2152.

Pietropaolo M, Eisenbarth GS. 2001. Autoantibodies in human diabetes. Curr Dir Autoimmun 4: 252-282.

Pietropaolo M, Becker DJ, LaPorte RE, Dorman JS, Riboni S, Rudert WA, Mazumdar S, Trucco M. 2002. Progression to insulin-requiring diabetes in seronegative prediabetic subjects: The role of two HLA-DQ high risk haplotypes. Diabetologia 45: 66-76.

Pietropaolo M, Yu S, Libman IM, Pietropaolo SL, Riley K, LaPorte RE, Drash AL, Mazumdar S, Trucco M, Becker DJ. 2005. Cytoplasmic islet cell antibodies remain valuable in defining risk of progression to type 1 diabetes in subjects with other islet autoantibodies. Pediatr Diabetes 6: $184-192$.

Pietropaolo M, Barinas-Mitchell E, Kuller LH. 2007. The heterogeneity of diabetes: Unraveling a dispute: Is systemic inflammation related to islet autoimmunity? Diabetes 56: 1189-1197.

Pugliese A, Kawasaki E, Zeller M, Yu L, Babu S, Solimena M, Moraes CT, Pietropaolo M, Friday RP, Trucco M, et al. 1999. Sequence analysis of the diabetes-protective human leukocyte antigen-DQB1*0602 allele in unaffected, islet cell antibody-positive first degree relatives and in rare patients with type 1 diabetes. J Clin Endocrinol Metab 84: $1722-1728$.

Rabinowe SL, Brown FM, Watts M, Kadrofske MM, Vinik AI. 1989. Anti-sympathetic ganglia antibodies and postural blood pressure in IDDM subjects of varying duration and patients at high risk of developing IDDM. Diabetes Care 12: 1-6. 
M. Pietropaolo et al.

Reijonen H, Mallone R, Heninger AK, Laughlin EM, Kochik SA, Falk B, Kwok WW, Greenbaum C, Nepom GT. 2004. GAD65-specific CD4 $4^{+}$T-cells with high antigen avidity are prevalent in peripheral blood of patients with type 1 diabetes. Diabetes 53: 1987-1994.

Roep BO, Duinkerken G, Schreuder GM, Kolb H, De Vries RR, Martin S. 1996. HLA-associated inverse correlation between $\mathrm{T}$ cell and antibody responsiveness to islet autoantigen in recent-onset insulin dependent diabetes mellitus. Eur J Immunol 26: 1285-1289.

Serreze DV, Chapman HD, Niens M, Dunn R, Kehry MR, Driver JP, Haller M, Wasserfall C, Atkinson MA. 2011. Loss of intra-islet CD20 expression may complicate efficacy of B-cell-directed type 1 diabetes therapies. Diabetes 60: 2914-2921.

Shoda LK, Young DL, Ramanujan S, Whiting CC, Atkinson MA, Bluestone JA, Eisenbarth GS, Mathis D, Rossini AA, Campbell SE, et al. 2005. A comprehensive review of interventions in the NOD mouse and implications for translation. Immunity 23: 115-126.

Skyler JS. 2011. Immune intervention for type 1 diabetes mellitus. Int J Clin Pract Suppl 2011: 61-70.

Skyler JS, Cefalu WT, Koudries IA, Landschulz WH, Balagtas CC, Cheng SL, Gelfand RA. 2001. Efficacy of inhaled human insulin in type 1 diabetes mellitus: A randomised proof-of-concept study. Lancet 357: 331-335.

Soderlin MK, Kastbom A, Kautiainen H, Leirisalo-Repo M, Strandberg G, Skogh T. 2004. Antibodies against cyclic citrullinated peptide (CCP) and levels of cartilage oligomeric matrix protein (COMP) in very early arthritis: Relation to diagnosis and disease activity. Scand J Rheumatol 33: 185-188.

Solimena M, Folli F, Denis-Donini S, Comi GC, Pozza G, De Camilli P, Vicari AM. 1988. Autoantibodies to glutamic acid decarboxylase in a patient with stiffman syndrome, epilepsy, and type I diabetes mellitus. $N$ Engl J Med 318: 1012-1020.

Stadinski BD, Delong T, Reisdorph N, Reisdorph R, Powell RL, Armstrong M, Piganelli JD, Barbour G, Bradley B, Crawford F, et al. 2010. Chromogranin A is an autoantigen in type 1 diabetes. Nat Immunol 11: 225-231.

Steck AK, Johnson K, Barriga KJ, Miao D, Yu L, Hutton JC Eisenbarth GS, Rewers MJ. 2011. Age of islet autoantibody appearance and mean levels of insulin, but not GAD or IA-2 autoantibodies, predict age of diagnosis of type 1 diabetes: Diabetes autoimmunity study in the young. Diabetes Care 34: 1397-1399.

Todd JA, Walker NM, Cooper JD, Smyth DJ, Downes K, Plagnol V, Bailey R, Nejentsev S, Field SF, Payne F, et al. 2007. Robust associations of four new chromosome regions from genome-wide analyses of type 1 diabetes. Nat Genet 39: 857-864.

Verge CF, Gianani R, Kawasaki E, Yu L, Pietropaolo M, Jackson RA, Chase PH, Eisenbarth GS. 1996. Prediction of type I diabetes mellitus in first degree relatives using a combination of insulin, glutamic acid decarboxylase and ICA512bdc/IA-2 autoantibodies. Diabetes 45: 926-933.

Verge CF, Stenger D, Bonifacio E, Colman PG, Pilcher C Bingley PJ, Eisenbarth GS. 1998. Combined use of autoantibodies (IA-2 autoantibody, GAD autoantibody, insulin autoantibody, cytoplasmic islet cell antibodies) in type 1 diabetes: Combinatorial Islet Autoantibody Workshop. Diabetes 47: 1857-1866.

Wasmeier C, Hutton JC. 1996. Molecular cloning of phogrin, a protein tyrosyne phosphatase homologue localized to insulin secretory granule membranes. J Biol Chem 271: 18161-18170.

Wenzlau JM, Juhl K, Yu L, Moua O, Sarkar SA, Gottlieb P, Rewers M, Eisenbarth GS, Jensen J, Davidson HW, et al. 2007. The cation efflux transporter ZnT8 (Slc30A8) is a major autoantigen in human type 1 diabetes. Proc Natl Acad Sci 104: 17040-17045.

Wenzlau JM, Moua O, Liu Y, Eisenbarth GS, Hutton JC Davidson HW. 2008. Identification of a major humoral epitope in Slc30A8 (ZnT8). Ann NYAcad Sci 1150: 252 255.

Wijesekara N, Chimienti F, Wheeler MB. 2009. Zinc, a regulator of islet function and glucose homeostasis. Diabetes Obes Metab 11: 202-214.

Wijesekara N, Dai FF, Hardy AB, Giglou PR, Bhattacharjee A, Koshkin V, Chimienti F, Gaisano HY, Rutter GA, Wheeler MB. 2010. $\beta$ cell-specific Znt8 deletion in mice causes marked defects in insulin processing, crystallisation and secretion. Diabetologia 53: 1656-1668.

Winer S, Tsui H, Lau A, Song A, Li X, Cheung RK, Sampson A, Afifiyan F, Elford A, Jackowski G, et al. 2003. Autoimmune islet destruction in spontaneous type 1 diabetes is not $\beta$-cell exclusive. Nat Med 9: 198-205.

Xiu Y, Wong CP, Bouaziz JD, Hamaguchi Y, Wang Y, Pop SM, Tisch RM, Tedder TF. 2008. B lymphocyte depletion by CD20 monoclonal antibody prevents diabetes in nonobese diabetic mice despite isotype-specific differences in Fc $\gamma$ R effector functions. J Immunol 180: 2863-2875.

Xu P, Wu Y, Zhu Y, Dagne G, Johnson G, Cuthbertson D, Krischer JP, Sosenko JM, Skyler JS. 2010. Prognostic performance of metabolic indexes in predicting onset of type 1 diabetes. Diabetes Care 33: 2508-2513.

Yu L, Liu Y, Miao D, Wenzlau J, Davidson H, Hutton J, Eisenbarth GS. 2010. Triple chimeric islet autoantigen IA2-ZnT8WR to facilitate islet autoantibody determination. J Immunol Methods 353: 20-23.

Yu L, Herold K, Krause-Steinrauf H, McGee PL, Bundy B, Pugliese A, Krischer J, Eisenbarth GS. 2011. Rituximab selectively suppresses specific islet antibodies. Diabetes 60: $2560-2565$.

Yu L, Miao D, Scrimgeour L, Johnson K, Rewers M, Eisenbarth GS. 2012. Distinguishing persistent insulin autoantibodies with differential risk: Nonradioactive bivalent proinsulin/insulin autoantibody assay. Diabetes 61: 179-186.

Zekavat G, Rostami SY, Badkerhanian A, Parsons RF, Koeberlein B, Yu M, Ward CD, Migone TS, Yu L, Eisenbarth GS, et al. 2008. In vivo BLyS/BAFF neutralization ameliorates islet-directed autoimmunity in nonobese diabetic mice. J Immunol 181: 8133-8144.

Zimmet PZ, Tuomi T, Mackay IR, Rowley MJ, Knowles W, Cohen M, Lang A. 1994. Latent autoimmune diabetes mellitus in adults (LADA): The role of antibodies to glutamic acid decarboxylase in diagnosis and prediction of insulin dependency. Diabet Med 11: 299-303. 


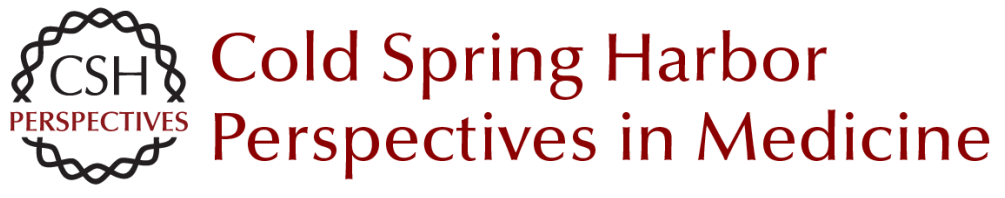

\title{
Humoral Autoimmunity in Type 1 Diabetes: Prediction, Significance, and Detection of Distinct Disease Subtypes
}

\author{
Massimo Pietropaolo, Roberto Towns and George S. Eisenbarth
}

Cold Spring Harb Perspect Med 2012; doi: 10.1101/cshperspect.a012831 originally published online August 17, 2012

\section{Subject Collection Type I Diabetes}

The Pathogenesis and Natural History of Type 1

Diabetes

Mark A. Atkinson

Do MHCII-Presented Neoantigens Drive Type 1 Diabetes and Other Autoimmune Diseases? Philippa Marrack and John W. Kappler

Clinical Immunologic Interventions for the Treatment of Type 1 Diabetes Lucienne Chatenoud, Katharina Warncke and Anette-G. Ziegler

Update on Islet Transplantation Michael McCall and A.M. James Shapiro

Immunologic and Metabolic Biomarkers of $\beta$-Cell

Destruction in the Diagnosis of Type 1 Diabetes Jasmin Lebastchi and Kevan C. Herold

Advancing Animal Models of Human Type 1

Diabetes by Engraftment of Functional Human

Tissues in Immunodeficient Mice Michael A. Brehm, Alvin C. Powers, Leonard D. Shultz, et al.

Breakdown in Peripheral Tolerance in Type 1

Diabetes in Mice and Humans Lukas T. Jeker, Hélène Bour-Jordan and Jeffrey $A$. Bluestone

Antigen-Specific Therapeutic Approaches in Type 1 Diabetes Xavier Clemente-Casares, Sue Tsai, Carol Huang, et al.
Humoral Autoimmunity in Type 1 Diabetes:

Prediction, Significance, and Detection of Distinct Disease Subtypes

Massimo Pietropaolo, Roberto Towns and George S. Eisenbarth

Endoplasmic Reticulum Stress, Pancreatic $\beta$-Cell Degeneration, and Diabetes Feroz R. Papa

Islet Autoantigens: Structure, Function, Localization, and Regulation Peter Arvan, Massimo Pietropaolo, David Ostrov, et al.

Environmental Triggers of Type 1 Diabetes Mikael Knip and Olli Simell

Generating $\beta$ Cells from Stem Cells--The Story So Far Matthias Hebrok

Antigen Targets of Type 1 Diabetes Autoimmunity Bart O. Roep and Mark Peakman

Connecting Type 1 and Type 2 Diabetes through Innate Immunity Justin I. Odegaard and Ajay Chawla

The Hygiene Hypothesis: An Explanation for the Increased Frequency of Insulin-Dependent Diabetes Jean-François Bach and Lucienne Chatenoud

For additional articles in this collection, see http://perspectivesinmedicine.cshlp.org/cgi/collection/ 